\title{
Canadian Tree Improvement Association 17th Meeting Gander, Newfoundland, August 1979
}

\begin{abstract}
"Tree Improvement in the Boreal Forest - Today and Tomorrow" was the theme of the meeting attended by over 60 foresters and scientists from Canada and the United States. The meeting was organized by Drs. M. A. K. Khalil and J. Peter Hall of the Newfoundland Forest Research Centre, St. John's. Generous financial support from government and private agencies assured attendance by speakers invited from across the continent.
\end{abstract}

In his opening remarks the Chairman, Mr. M. F. (Mac) Squires, emphasized the urgent need to create genetically improved seed and planting stock for rapidly accelerating intensive forest management programs in boreal Canada. Greater effort and support are needed and every advantage must be taken of new techniques to hasten the breeding process. Because of the very large investments to be made in regeneration and tree improvement it is essential that they be based on a sound foundation of research.

The Minister for Forests and Agriculture, Government of Newfoundland and Labrador, the Honorable Mr. James C. Morgan, welcomed the delegates and pledged his government's support to an expanding tree improvement program in the province.

"Cooperative Tree Improvement in Canada" was the title of a half-day workshop which included presentations by six speakers from five provinces dealing with governmentindustry collaboration in applied genetics. The feeling of many was expressed by Bruce Devitt, Chief Forester of the Pacific Logging Co. Ltd., B.C., when commenting on his 23 years of "growing up" with government and industry tree improvement programs. He said:

"The expansion into intensive forestry across the country is going to be deterred through the lack of competent people. Our training and research sections are at their weakest at a time when they should be at their strongest. All of us need to request and demand that politicians, governments, and training institutions coordinate and develop compatible policies in the funding of research and the development of trained people.

In addition, scientists have a basic responsibility to do pertinent research on a 'need to know' rather than a 'nice to know' basis. Communication of important findings to user groups should be in a language and format easily understood.

The politicians and the general public will also be demanding the best of scientific advice and your (our) challenge as scientists will be to provide it."

A day of sunshine and balmy temperatures was spent viewing species and provenance trials established by the Canadian Forestry Service in the North Pond Forest Experimental Area. Species included native and exotic spruces, pines, larches and firs which demonstrated a wide range of adaptability to demanding conditions of site and climate. Delegates were treated to an outdoor barbecue of fresh cod, salmon, baked beans, homemade bread, partridgeberry jam and Newfoundland beverages.

A full day symposium addressed the main theme of the meeting with papers and discussions dealing with conventional and innovative techniques for identification and propagation of superior populations of trees, the starting point in genetic improvement. Eleven authors from Canada and the United States dealt with a diversity of subject matter including: clonal and progeny tests (Dr. E. Kris Morgenstern); seed source selection (Dr. Hans Nienstaedt); seed orchard management (Miss R. Marie Rauter); the rôle of hybrid poplars in wood production (Dr. Louis Zsuffa); breeding strategy (Dr. Hyun Kang); cooperative programs (Dr. R. C. (Bob) Kellison); physiological techniques to reduce time between generations (Dr. R. B. (Rick) Hall); the potential of isoenzyme analyses (Dr. Francis C. Yeh and Dr. M. Thompson Conkle); biosystematics, biochemistry and quantitative genetics (Dr. Peter P. Feret); and the status and rôle of tissue culture (Dr. Donald J. Durzan). These papers and an account of the discussions will be published as Part 2 of the Proceedings, 17 th Meeting C.T.I.A.IA.C.A.A.

At the business meeting of the Association new members were elected and a standing committee appointed on Forest Genetics Education. The need for funding of graduate training and research in forest genetics was seen to be a first priority for tree improvement in Canada.

The 18th Meeting will be held in August 1981 on Vancouver Island, British Columbia, hosted by the B.C. Forest Service. The 19th Meeting scheduled for 1983 will be held in Ontario. Officers elected for 1979-81 include: Mr. J. C. Heaman, B.C. Forest Service, Chairman; Dr. D. F. W. Pollard, Canadian Forestry Service, Vice-Chairman (symposium); Mr. M. Crown, B.C. Forest Service, Vice-Chairman (local arrangements); Dr. N. K. Dhir, Alberta Forest Service, Executive Secretary; Dr. C. W. Yeatman, Canadian Forestry Service, Editor; and Mr. M. F. Squires, Abitibi-Price Inc., past-Chairman.

The Proceedings are distributed widely within Canada and abroad. Part 1 includes biennial progress reports on tree genetics, breeding and seed production research and application from Active Members coast to coast. Canadians not on the mailing list who wish to receive the proceedings are advised to request corresponding membership by writing to Dr. N. K. Dhir, Executive Secretary, C.T.I.A., Reforestation and Reclamation Branch, Department of Energy and Natural Resources, Edmonton, Alberta, T5K $2 \mathrm{C} 9$.

Malcolm F. Squires

Chairman (1977-1979)

Canadian Tree Improvement Association 